\title{
PERMASALAHAN DAN REKOMENDASI DALAM PEMBENTUKAN BADAN PENYELESAIAN SENGKETA KONSUMEN KABUPATEN BEKASI PROVINSI JAWA BARAT
}

\author{
Medi Nopiana ${ }^{1)}$ \\ Agus Maulana ${ }^{2)}$ \\ ${ }^{1}$ Fakultas Ekonomi dan Bisnis Universitas Singaperbangsa Karawang \\ Email: medinopiana@gmail.com \\ ${ }^{2}$ Sekolah Bisnis, Institut Pertanian Bogor \\ Email: agus.maulana0508@gmail.com
}

\begin{abstract}
ABSTRAK
Penelitian ini bertujuan mengidentifikasi berbagai permasalahan yang diduga akan dihadapi dalam pembentukan dan pengoperasian Badan Penyelesaian Sengketa Konsumen (BPSK) Kabupaten Bekasi. Selanjutnya, penelitian ini bertujuan menyusun rekomendasi dalam pembentukan BPSK di Kabupaten Bekasi. Metode analisis menggunakan analisis deskriptif kualitatif. Sedangkan metode pengumpulan data menggunakan studi pustaka dan wawancara mendalam. Hasil penelitian menunjukkan, permasalahan yang diduga akan dihadapi, yaitu menyangkut aspek anggaran, aspek kepersonaliaan, dan aspek hubungan dengan institusi hukum yang lain. Untuk itu, rekomendasi yang disampaikan antara lain mengenai anggaran yang perlu disiapkan, serta struktur dan komposisi anggota BPSK.
\end{abstract}

Kata kunci: Perlindungan Konsumen, BPSK, Kabupaten Bekasi

\section{PENDAHULUAN}

Penerapan Undang-undang No. 8 Tahun 1999 tentang Perlindungan Konsumen merupakan upaya untuk menjamin adanya kepastian hukum dalam memberi perlindungan kepada konsumen. Hal tersebut bertujuan untuk meningkatkan kesejahteraan masyarakat, dengan mendapatkan kepastian atas barang dan atau jasa yang diperoleh dari perdagangan tanpa mengakibatkan kerugian konsumen. Kepastian yang dimaksud meliputi mutu, jumlah dan keamanan barang dan/atau jasa yang diperolehnya di pasar. 
Pada pasal 29 ayat (1) dalam aturan perundangan di atas menyatakan bahwa Pemerintah bertanggung jawab atas pembinaan penyelenggaraan perlindungan konsumen yang menjamin diperolehnya hak konsumen dan pelaku usaha serta dilaksanakannya kewajiban konsumen dan pelaku usaha. Lebih lanjut, dalam Pasal 49 ayat (1) juga menyebutkan bahwa Pemerintah membentuk badan penyelesaian sengketa konsumen di Daerah Tingkat II untuk penyelesaian sengketa konsumen di luar pengadilan. Badan Penyelesaian Sengketa Konsumen (BPSK) adalah badan yang bertugas menangani dan menyelesaikan sengketa antara pelaku usaha dan konsumen.

Salah satu kabupaten/kota di Indonesia yang tengah berupaya membentuk BPSK adalah Kabupaten Bekasi. Kebutuhan akan kehadiran BPSK di Kabupaten Bekasi telah mendesak. Berdasarkan penelitian Nopiana dan Maulana (2017), urgensi pembentukan BPSK di Kabupaten Bekasi didasarkan antara lain pesatnya perkembangan ekonomi dan tingkat kesejahteraan masyarakat serta meningkatnya masyarakat kelas menengah di Kabupaten Bekasi. Kondisikondisi di atas membawa konsekuensi makin tingginya kualitas pendidikan masyarakat, sehingga menumbuhkan sikap kritis masyarakat terhadap produk-produk yang dikonsumsinya. Perilaku tersebut menandai makin meningkatnya kemungkinan sengketa konsumen dengan pelaku usaha di Kabupaten Bekasi.

Dalam pembentukan BPSK di Kabupaten Bekasi diperlukan kajian tentang dua hal. Pertama, mengidentifikasi berbagai permasalahan yang diduga akan dihadapi dalam pembentukan dan pengoperasian BPSK Kabupaten Bekasi. Kedua, menyusun rekomendasi dalam pembentukan BPSK di Kabupaten Bekasi.

\section{METODE PENELITIAN}

Dalam penelitian ini, metode analisis data yang digunakan adalah metode analisis deskriptif kualitatif. Adapun data dan informasi yang dibutuhkan dalam penelitian ini dikumpulkan melalui penggalian sumber-sumber pustaka dan wawancara mendalam (in-depth interview). Studi pustaka dilakukan pada tahap awal, dengan tujuan untuk memelajari berbagai dokumen hukum, literatur dan kajian sebelumnya yang berkaitan dengan perlindungan konsumen dan pembentukan lembaga BPSK. Hasil studi penelusuran dokumen ini digunakan untuk menyusun pedoman rancangan pertanyaan untuk wawancara mendalam. Wawancara untuk mendapatkan data primer dilakukan kepada narasumber di BPSK dan Dinas Perindustrian dan 
Perdagangan kabupaten/kota terpilih, serta para pejabat di lingkungan Pemerintah Kabupaten Bekasi.

Jenis data yang digunakan dalam penelitian ini adalah data primer yang diperoleh melalui wawancara secara mendalam dengan para pemangku kepentingan terpilih di Kabupaten Bekasi, seperti Badan Perencanaan Pembangunan Daerah dan Dinas Perindustrian, Perdagangan, Koperasi dan Usaha Mikro, Kecil dan Menengah. Data primer dalam penelitian ini juga diperoleh melalui kegiatan kunjungan ke BPSK serta Dinas Perindustrian dan Perdagangan di kabupaten/kota lain yang terdekat (Kabupaten Karawang dan Kota Bogor). Pemilihan kabupaten/kota tersebut dengan alasan bahwa jarak keduanya dengan wilayah Kabupaten Bekasi berdekatan, sehingga karakteristik perekonomian dan perilaku masyarakat yang relatif sama, sehingga memudahkan untuk memahami berbagai permasalahan yang terjadi dalam pembentukan BPSK.

\section{GAMBARAN BPSK DI KABUPATEN/KOTA LAIN}

\section{Gambaran Umum BPSK Kota Bogor}

BPSK Kota Bogor dibentuk berdasarkan Keputusan Presiden Nomor 108 tahun 2004 tentang Pembentukan Badan Penyelesaian Sengketa Konsumen (BPSK). Sebagai tindak-lanjut keputusan tersebut, Menteri Perdagangan Republik Indonesia kemudian mengeluarkan Keputusan Menteri Perdagangan Republik Indonesia Nomor 224/M-DAG/Kep/6/2005 tentang pengangkatan anggota BPSK Kota Bogor. Sesuai keputusan ini anggota BPSK Kota Bogor berjumlah sembilan orang yang terdiri atas unsur pemerintah tiga orang, unsur pelaku usaha tiga orang, dan unsur konsumen tiga orang. H. Rafinus Sukri, S.H. dari unsur pemerintah ditunjuk menjadi ketua. Saat ini, kepengurusan BPSK Kota Bogor diketuai oleh Drs. Mangahit Sinaga, M.M. Komposisi dan jumlah anggota tetap tidak berubah yaitu sembilan orang, dengan masingmasing tiga orang dari setiap unsur, yang secara rinci adalah sebagai berikut:

1. Drs. Mangahit Sinaga, M.M., Ketua merangkap anggota (Pemerintah)

2. Amik Herdwiyastuti, S.H., M.Si., anggota (Pemerintah)

3. Boris Derurasman, S.H., Sp.N., anggota (Pemerintah)

4. Ir. H. Sonny Novansyah, anggota (Pelaku usaha)

5. J. Jopie Gilalo, S.H., Wakil Ketua merangkap anggota (Pelaku usaha)

6. Ir. Setiabudiningsih, anggota (Pelaku usaha) 
7. Ir. Moh. Kisman Pangeran, anggota (Konsumen)

8. Agus Satory, S.H., anggota (Konsumen)

9. Drs. Yayan Carsiyan, anggota (Konsumen)

Komposisi keanggotaan BPSK Kota Bogor yang mengikuti formasi 3x3 (artinya, tiga anggota dari masing-unsur pemerintah, pelaku usaha, dan konsumen) sudah sesuai dengan UU No.8 Tahun 1999 yang menetapkan jumlah keanggotaan BPSK antara 9 dan 15 orang dengan komposisi tiga unsur yang sama. Jumlah ini juga dirasakan memadai mengingat luas wilayah Kota Bogor yang tidak terlalu besar dan dipandang sesuai dengan anggaran yang ada.

Pengurus BPSK Kota Bogor dalam kegiatannya dibantu oleh sekretariat yang beranggotakan lima orang, yaitu Dra. Wigati Handayani sebagai ketua, Nike Sylviawati, S.Si., Bayu Citra Fahreza, S.Kom, M.Si., Adrian Aditya Nagara, S.E., M.Ak., dan Heri Chaerudin, S.E., masing-masing sebagai anggota. Kelima pengurus sekretariat adalah PNS di Pemda Kota Bogor. Selain itu, BPSK Kota Bogor juga didukung oleh dua orang pembantu sekretariat. Satu orang pembantu sekretariat adalah PNS dan lainnya non-PNS. Diperoleh informasi dari BPSK Kota Bogor bahwa dalam menentukan anggota BPSK dari unsur pemerintah ada kecenderungan untuk mengambil dari PNS Golongan IV di lingkungan SKPD yang mengurusi perdagangan yang memiliki jabatan struktural. Pertimbangan pemilihan ini adalah agar anggota yang ditunjuk memiliki pengetahuan dan pengalaman yang memadai di bidang yang menyangkut hubungan antara konsumen dan pelaku usaha serta memiliki wibawa yang cukup untuk mengendalikan BPSK dan memilihara komunikasi di antara tiga unsur yang ada.

BPSK Kota Bogor telah bekerja mulai tahun 2005 dan telah menyelesaikan berbagai kasus perdata yang melibatkan pelaku usaha dengan konsumen. Penyelesaian sengketa diselesaikan dengan cara Konsiliasi, Mediasi, dan Arbitrase. Cara ketiga, arbitrase, merupakan cara terakhir yang hanya dilakukan apabila kedua cara pertama gagal menyelesaikan masalah. BPSK Bogor berpandangan bahwa sebaiknya setiap masalah sengketa dapat diselesaikan secara konsiliasi atau mediasi. Batas waktu penyelesaian sengketa di BPSK Bogor adalah sesuai dengan yang ditetapkan, yaitu paling lama 21 hari kerja setelah gugatan diterima. Keputusan BPSK merupakan keputusan final dan mengikat kedua pihak, yaitu pelaku usaha dan konsumen.

Jumlah perkara yang ditangani BPSK Kota Bogor bervariasi dari tahun ke tahun. Pada tahun 2011 berhasil diselesaikan 10 perkara, 2012 sebanyak 24 perkara, 2013 sebanyak 14 
perkara ditambah dua perkara yang baru diselesaikan di tahun 2014. Tahun 2014 sendiri sampai laporan ini dibuat sudah diselesaikan 12 perkara (ditambah dua perkara sisa tahun 2013).

Operasi BPSK Kota Bogor dibiayai dari APBD Pemda Bogor, yaitu sebagai bagian dari anggaran Disperindag Kota Bogor. Pada tahun 2014 anggaran BPSK Kota Bogor adalah sebesar Rp.245 juta. Jumlah ini relatif tidak terlalu bervariasi sejak tahun 2005 (Rp.225 juta). Jika dilihat dari anggaran Diseprindag Kota Bogor tahun 2014 yang sebesar sekitar Rp.6 miliar, berarti anggaran BPSK adalah 4,08 persen dari anggaran Disperindag Kota Bogor. Jika dibandingkan dengan APBD Kota Bogor yang sekitar Rp.1,94 triliun, maka anggaran BPSK Kota Bogor adalah sebesar sekitar 0,01 persen.

\section{Gambaran Umum BPSK Kabupaten Karawang}

BPSK Kabupaten Karawang dibentuk berdasarkan Keputusan Presiden Nomor 18 tahun 2010 tentang Pembentukan Badan Penyelesaian Sengketa Konsumen (BPSK) di Kota Serang, Kota Kendari, Kota Bukittinggi, Kota Singkawang, Kota Pontianak, Kabupaten Kotawaringin Barat, Kabupaten Padangpariaman, Kabupaten Karawang, dan Kabupaten Batu Bara. Sebagai tindak-lanjut keputusan tersebut, Menteri Perdagangan Republik Indonesia kemudian mengeluarkan Keputusan Menteri Perdagangan Republik Indonesia Nomor 704/MDAG/KEP/9/2011 tentang Pengangkatan Anggota Badan Penyelesaian Sengketa Konsumen pada Pemerintah Kabupaten Karawang.

Sesuai keputusan tersebut, anggota BPSK Kabupaten Karawang berjumlah 15 (lima belas) orang yang terdiri atas unsur pemerintah 5 (lima) orang, unsur pelaku usaha 5 (lima) orang, dan unsur konsumen 5 (lima) orang. Saat ini, kepengurusan BPSK Kabupaten Karawang diketuai oleh Drs. Daud Munasto, S.H., M.H. yang berasal dari unsur pemerintah. Secara rinci, komposisi dan jumlah anggota BPSK Kabupaten Karawang adalah sebagai berikut:

1. Drs. Daud Munasto, S.H., M.H., ketua merangkap anggota (pemerintah)

2. Nino Sukirno, wakil ketua merangkap anggota (pelaku usaha)

3. H. Anwar Musadad, S.E., M.M., anggota (pemerintah)

4. Puryanto, S.H., anggota (pemerintah)

5. Fatahilah, S.K.M., anggota (pemerintah)

6. Banjar Sulismantoro, anggota (pemerintah)

7. Imam Budi S., S.H., M.H., anggota (konsumen) 
8. Dul Jalil, S.H., anggota (konsumen)

9. Sayono Abikoesno, anggota (konsumen)

10. Wawan Gunawan, anggota (konsumen)

11. Edi Junaedi, anggota (konsumen)

12. M. Holyone N.S., S.H., M.H., anggota (pelaku usaha)

13. Dr. Puji Isyanto, anggota (pelaku usaha)

14. R. Hendra Sulistyawan, S.H., anggota (pelaku usaha)

15. R. Ade Kesatriadi, anggota (pelaku usaha)

Visi BPSK Kabupaten Karawang adalah "terwujudnya upaya penyelesaian sengketa konsumen dalam rangka pemberdayaan dan perlindungan masyarakat, sehingga tercapainya peningkatan kualitas barang dan pelayanan jasa di Kabupaten Karawang dan sekitarnya". Sedangkan misi BPSK Kabupaten Karawang, yaitu:

1. Mewujudkan Kabupaten Karawang sebagai kota industri yang bermartabat sehingga memacu terciptanya situasi ekonomi yang kondusif dan menguntungkan dengan mengutamakan perlindungan konsumen;

2. Mewujudkan kemandirian dan keberdayaan konsumen dalam mempertahankan hak dan menjalankan kewajibannya sehingga terangkat harkat dan martabatnya sebagai kosumen;

3. Mewujudkan sistim perlindungan yang mengandung unsur kepastian hukum, keadilan dan manfaat secara berimbang bagi konsumen dan pelaku usaha;

4. Menumbuhkan kesadaran pelaku usaha untuk bersikap jujur dan bertanggung jawab sehingga mampu menjamin kelangsungan usaha dan perlindungan konsumen.

\section{HASIL DAN PEMBAHASAN}

\section{Berbagai Permasalahan yang dihadapi dalam Pembentukan dan Operasional BPSK Kabupaten Bekasi}

Dalam memahami berbagai permasalahan yang dihadapi pada tahap pembentukan dan operasional BPSK Kabupaten Bekasi, diperlukan lesson learned ${ }^{l}$ dari berbagai BPSK kabupaten/kota lain, khususnya yang berdekatan dengan wilayah Kabupaten Bekasi. Hal ini

\footnotetext{
${ }^{1}$ Pengetahuan yang diperoleh melalui pengalaman, jika dibagi dapat bermanfaat bagi pihak lain.
} 
disebabkan karena karakteristik perekonomian dan perilaku masyarakat yang relatif sama, akan memudahkan untuk memahami berbagai permasalahan yang terjadi.

\section{Aspek Anggaran}

Berdasarkan hasil wawancara dengan pihak BPSK Kota Bogor diketahui bahwa sebetulnya jumlah perkara yang dapat ditangani sangat tergantung pada anggaran yang tersedia, dan banyaknya perkara yang ditangani sudah tercantum dalam anggaran yang dibuat setiap tahun. Hal ini dirasakan juga menjadi masalah karena BPSK Kota Bogor mengalami kesulitan untuk memerkirakan jumlah perkara yang akan perlu ditangani pada tahun anggaran berikutnya, sementara usulan anggaran sudah harus disampaikan sekitar kuartal 3 tahun berjalan (untuk kegiatan tahun berikutnya).

Dari pengalaman, sangat mungkin terjadi bahwa target jumlah perkara yang ditangani sudah tercapai agak jauh sebelum tahun anggaran berakhir. Jika target perkara yang ditangani sesuai anggaran telah tercapai sebelum tahun anggaran berakir sementara masih ada masyarakat (konsumen) yang mengajukan perkaranya, maka BPSK Kota Bogor terpaksa minta kerelaan majelis untuk menangani perkara tersebut tanpa honor sidang. Hal ini sampai sekarang tidak menjadi masalah karena para anggota BPSK Kota Bogor memang bekerja lebih karena dorongan keinginan pengabdian dan tidak semata mengejar penghasilan (semua anggota memiliki sumber penghasilan sendiri sehingga tidak ada yang bergantung pada penghasilan dari BPSK). Namun demikian, dirasakan sudah sepantasnya jika BPSK sebagai lembaga di bawah naungan Disperindag tidak terlalu mengandalkan niat pengabdian para anggotanya.

Sebagai informasi, anggaran operasional BPSK Kota Bogor yang dialokasikan untuk membayar honor pengurus BPSK termasuk sekretariat dan pembantu sekretariat, dengan rincian sebagai berikut:

- Honor Ketua Rp 1,6 juta/bulan;

- Honor Wakil Ketua Rp 1,4 juta/bulan;

- Honor Anggota Rp 1,2 juta/bulan/orang;

- Kepala Sekretariat $\mathrm{Rp} 750$ ribu/bulan;

- Sekretariat Rp 630 ribu/bulan/orang;

- Pembantu sekretariat Pegawai Negeri Sipil (PNS) Rp 450 ribu/bulan; 


\section{- Pembantu sekretariat non-PNS Rp 750 ribu/bulan.}

Selain itu untuk setiap kali sidang, para anggota majelis mendapat honor sebesar Rp 300 ribu/orang, sedangkan panitera menerima honor Rp 225 ribu. Untuk pembuatan putusan, setiap anggota majelis menerima honor $\mathrm{Rp} 125$ ribu/orang. Jika untuk suatu perkara majelis memandang perlu untuk mendatangkan saksi ahli, maka saksi ahli PNS menerima honor Rp 350 ribu, sedangkan saksi ahli non-PNS menerima honor Rp 500 ribu. Pada tahun anggaran 2014 BPSK Kota Bogor menyediakan anggaran untuk saksi ahli sebanyak tiga orang, tetapi hanya terpakai untuk satu orang saja (sampai saat wawancara dilakukan). Selain untuk membayar honor, anggaran BPSK juga digunakan untuk biaya operasional lain, seperti alat tulis dan kantor. Secara nyata, sebetulnya masih ada biaya-biaya lain, khususnya yang harus dikeluarkan oleh anggota sekretariat untuk melakukan pemanggilan pihak yang berperkara, tetapi biaya ini sudah termasuk dalam honor para anggota sekretariat. Secara rata-rata, biaya yang dibutuhkan untuk menangani satu perkara sampai selesai adalah Rp 1,5 juta.

Angka-angka di atas menunjukkan bahwa sebagian besar anggaran BPSK Kota Bogor digunakan untuk membayar honor anggota dan sekretariat (sejumlah Rp 190.440.000 setahun). Artinya, tersisa sekitar Rp 55 juta untuk penyelenggaraan sidang dan operasional BPSK.. Jika diasumsikan BPSK Kota Bogor menangani 15 perkara per tahun, maka akan dibutuhkan biaya sidang sebesar Rp 22,5 juta. Masih tersedia sekitar Rp. 32,5 juta untuk membiayai operasi BPSK Kota Bogor.

\section{Aspek Personalia}

Berdasarkan wawancara dengan pihak Dinas Perindustrian, Perdagangan, Pertambangan dan Energi (Disperindagtamben) Kabupaten Karawang, pengurus BPSK yang berasal dari unsur pemerintah seringkali dihadapkan pada kurangnya fokus dalam menghadapi tugas-tugas yang diembannya. Hal ini disebabkan pengurus BPSK tersebut juga merangkap sebagai pejabat struktural di SKPD dalam lingkup Pemerintah Daerah Kabupaten Karawang. Selain itu menurut pengalaman selama ini, rendahnya integritas dan komitmen pengurus BPSK juga acapkali menjadi permasalahan dalam menjalankan fungsi BPSK secara optimal. Cukup banyak PNS di berbagai SKPD dan unsur lain yang memiliki kemampuan untuk mengemban tugas sebagai pengurus BPSK. Namun pada kenyataannya, hanya sedikit PNS atau unsur lain yang memiliki 
integritas dan komitmen yang tinggi untuk menjalankan tugas-tugas di BPSK. Untuk itu, mereka menyarankan untuk merekrut pengurus BPSK dari unsur pemerintah berasal dari PNS nonstruktural yang telah diketahui rekam jejaknya memiliki integritas dan komitmen tinggi dalam menjalankan tugas-tugas kepemerintahan khususnya. Untuk memperoleh kualifikasi pengurus BPSK yang diinginkan, tahapan penyeleksian pengurus haruslah ditempuh secara adil dan transparan.

Hal kedua, untuk memudahkan koordinasi dan komunikasi antara Disperindagtamben dengan BPSK, disarankan pengurus dan anggota sekretariat BPSK seluruhnya berasal dari Disperindagtamben. Khusus untuk Sekretarias BPSK disarankan untuk dirangkap oleh kepala seksi yang menangani perlindungan konsumen di lingkup Disperindagtamben. Hal ini untuk memudahkan proses administrasi keuangan, terutama terkait dengan anggaran yang dialokasikan untuk operasional BPSK, sebagai Pejabat Pelaksana Teknis Kegiatan (PPTK).

\section{Aspek Koordinasi dan Komunikasi dengan Institusi Hukum Lainnya}

Berdasarkan pengalaman yang disampaikan BPSK Kabupaten Karawang, menekankan pentingnya koordinasi komunikasi dengan institusi hukum lainnya, seperti Kepolisian Resor dan Pengadilan Negeri. Hal ini bertujuan antara lain untuk mengarahkan masyarakat untuk menempuh penyelesaian sengketa konsumen melalui BPSK, mengingat belum seluruhnya masyarakat mengetahui keberadaan dan fungsi BPSK. Agar tercipta kesetaraan pemahaman dengan Pengadilan Negeri, BPSK Kabupaten Karawang selalu mendiskusikan dasar hukum yang menjadi landasan dalam menyelesaikan kasus-kasus yang berkaitan dengan perlindungan konsumen.

\section{SIMPULAN}

1. Masalah yang berpotensi akan dihadapi Kabupaten Bekasi dalam pembentukan dan pengoperasian BPSK dapat dikelompokkan ke dalam tiga masalah utama, yaitu menyangkut aspek anggaran, aspek kepersonaliaan, dan aspek hubungan dengan institusi hukum yang lain.

2. Dalam kaitan dengan pembentukan BPSK Kabupaten Bekasi disampaikan rekomendasi khususnya mengenai anggaran yang perlu disiapkan, dan struktur dan komposisi anggota 
BPSK dengan mengingat pentingnya hubungan yang baik antara BPSK dan institusi hukum yang lain. Selain itu, diberikan juga rekomendasi mengenai persiapan pembentukan BPSK Kabupaten Bekasi.

\section{REKOMENDASI}

Dari kajian yang dilakukan, dapatlah diberikan beberapa rekomendasi bagi Pemerintah Daerah Kabupaten Bekasi dalam rangka pembentukan BPSK Kabupaten Bekasi.

1. Permohonan pembentukan BPSK Kabupaten Bekasi hendaknya diajukan secepatnya, karena menurut pengalaman diperlukan waktu sekitar 1 tahun sejak permohonan disampaikan sampai keluarnya keputusan pemerintah tentang pembentukan BPSK.

2. Pemerintah Kabupaten Bekasi diharapkan segera membentuk tim seleksi untuk merekrut dan menyeleksi pengurus BPSK. Struktur organisasi BPSK disesuaikan dengan undangundang dan peraturan yang ada, dan disarankan beranggotakan 15 orang dengan memerhatikan komposisi yang sudah diatur, yaitu lima orang dari masing-masing unsur (pemerintah, pelaku usaha, dan konsumen). Jumlah 15 orang ini direkomendasikan mengingat luasnya wilayah Kabupaten Bekasi $^{2}$ dan tingginya potensi sengketa yang mungkin terjadi. Keanggotaan BPSK ini tentu juga perlu disesuaikan dengan cakupan kegiatan dan rencana kerja BPSK, yang selanjutnya akan berdampak pada penyediaan anggaran bagi BPSK.

3. Tim atau panitia seleksi yang dibentuk disarankan untuk diketuai oleh pejabat tinggi di lingkungan Pemerintah Kabupaten Bekasi (misalnya Sekretaris Daerah), agar proses seleksi dapat berjalan secara efektif. Panitia seleksi disarankan untuk memanfaatkan berbagai sarana komunikasi yang ada, untuk menyebarluaskan informasi tentang seleksi yang akan dilakukan, agar calon anggota yang dihasilkan benar-benar berkualitas. Sosialisasi seleksi melalui berbagai jejaring sosial dan media elektronik (radio setempat) serta media cetak lokal, seperti Info Bekasi juga disarankan untuk dimanfaatkan.

4. Anggota dari unsur pemerintah sebaiknya berasal dari SKPD Disperindagkop UMKM Kabupaten Bekasi yang merupakan PNS dengan golongan IV. Mengingat jumlah unsur pemerintah yang diusulkan adalah lima orang, maka diharapkan ada kombinasi antara PNS

\footnotetext{
${ }^{2}$ Kabupaten Bekasi memiliki cakupan wilayah 127.388 ha dengan jumlah penduduk sebanyak lebih kurang 3,25 juta jiwa (berdasarkan data Badan Pusat Statistik tahun 2015).
} 
yang memiliki jabatan struktural dan yang merupakan PNS fungsional, agar operasi BPSK dapat berjalan tanpa banyak berbenturan dengan tugas-tugas lain yang juga diemban para anggota tersebut sebagai PNS. Hal ini dirasakan perlu karena BPSK perlu memiliki wibawa yang cukup agar dapat menangani perkara-perkara yang melibatkan masyarakat dan pelaku usaha. Sebaiknya ada anggota dari unsur pemerintah yang memiliki pengetahuan dan pengalaman di bidang hukum perdata, khususnya bisnis. Komposisi seperti ini diharapkan dapat mendukung terciptanya koordinasi dan komunikasi dengan Disperindagkop UMKM serta dapat fokus dalam menghadapi tugas-tugas di BPSK.

5. Anggota dari unsur pelaku usaha sebaiknya berasal dari pelaku usaha yang dikenal memiliki reputasi baik dan menunjukkan sikap dan perilaku bisnis yang bertanggung jawab sosial. Sebaiknya ada anggota dari unsur ini yang berlatar-belakang pendidikan dan/atau pengalaman di bidang hukum bisnis.

6. Anggota dari unsur konsumen disarankan berasal dari organisasi/lembaga yang selama ini dikenal sebagai pembela hak konsumen. Diharapkan anggota dari unsur konsumen adalah mereka yang juga mengerti hukum dan mampu bersikap fair.

7. Anggota sekretariat sebaiknya adalah PNS di lingkungan Disperindagkop UMKM yang tidak memiliki posisi struktural, tetapi diharapkan memiliki kualifikasi yang memungkinkan mereka melaksanakan tugas-tugas kesekretariatan, khususnya yang berkaitan dengan proses hukum dan administrasi.

8. Pemerintah Kabupaten Bekasi disarankan untuk segera menyiapkan anggaran untuk BPSK dengan memerhatikan kondisi ekonomi Bekasi serta ketersediaan calon anggota BPSK. Dengan mengingat kondisi PDRB Kabupaten Bekasi yang termasuk tinggi di Provinsi Jawa Barat, disarankan agar honor bagi anggota BPSK termasuk sekretariat dan pembantu sekretariat lebih tinggi daripada BPSK Kota Bogor dan Kabupaten Karawang. Dalam anggaran tersebut sebaiknya juga dimasukkan pos operasional BPSK secara rinci dan juga pos untuk kegiatan sosialisasi BPSK. Mengingat luasnya wilayah Kabupaten Bekasi, disarankan agar anggaran yang disediakan untuk BPSK adalah sekitar 0,02 sampai 0,025 persen dari total belanja APBD Kabupaten Bekasi ${ }^{3}$.

\footnotetext{
${ }^{3}$ Kisaran persentase anggaran BPSK terhadap total belanja APBD disarankan agar lebih besar dari persentase anggaran BPSK Kabupaten Karawang (0,02\%) dan Kota Bogor (0,01\%).
} 
9. Disperindagkop UMKM diharapkan dapat membentuk tim untuk menyusun rencana kerja dan anggaran BPSK Kabupaten Bekasi, bekerja sama dengan Bappeda Kabupaten Bekasi.

10. BPSK Kabupaten Bekasi yang terbentuk harus mampu melaksanakan koordinasi dengan Kepolisian Resor Kabupaten Bekasi dan Pengadilan Negeri Kabupaten Bekasi, terutama dalam mengarahkan pengaduan masyarakat mengenai perlindungan konsumen. Selain itu, agar tercipta kesetaraan pemahaman dengan Pengadilan Negeri Kabupaten Bekasi, BPSK harus selalu berinisiatif mendiskusikan dasar hukum yang menjadi landasan dalam menyelesaikan kasus-kasus yang berkaitan dengan perlindungan konsumen.

\section{KETERBATASAN PENELITIAN}

Penelitian ini memiliki keterbatasan, yakni masih mengacu pada Keputusan Menteri Perdagangan No.13/M-DAG/PER/3/2010 tentang Pengangkatan dan Pemberhentian Anggota Badan Penyelesaian Sengketa Konsumen dan Sekretariat Badan Penyelesaian Sengketa Konsumen. Hal ini disebabkan saat kajian pembentukan BPSK di Kabupaten Bekasi dilakukan, Peraturan Menteri Perdagangan No.06/M-DAG/PER/2/2017 tentang Badan Penyelesaian Sengketa Konsumen belum diterbitkan. Oleh karena itu, untuk penelitian pembentukan BPSK selanjutnya diharapkan mengacu pada perkembangan terkini sebagaimana ketentuan di atas.

\section{DAFTAR PUSTAKA}

Kementerian Perdagangan Republik Indonesia, 2010, Peranan Badan Penyelesaian Sengketa Konsumen (BPSK), Direktorat Perlindungan Konsumen, Direktorat Jenderal Perdagangan Dalam Negeri.

Badan Pusat Statistik, 2016, Kabupaten Bekasi Dalam Angka 2015, Katalog BPS: 1102001.3216 .

Badan Pusat Statistik, 2016, Statistik Daerah Kabupaten Bekasi 2016, Katalog BPS: 1101002.3216 .

Dyarini M., Anggia, 2011, Tanggung Jawab Hukum Pelaku Usaha Perangkat Lunak kepada Konsumen: Kajian Perbandingan Lisensi Standard Software, Bespoke Software dan 
Customized Software, Tesis, Program Magister Hukum Fakultas Hukum Universitas Indonesia, Jakarta.

Marwanti, Dwi Ira, 2010, Upaya Perlindungan Hukum bagi Konsumen melalui BPSK dan Peradilan Umum (Studi tentang Perbandingan Efektivitas Mekanisme Penyelesaian Beberapa Sengketa Konsumen melalui BPSK Provinsi DKI Jakarta dan Pengadilan Negeri Jakarta Pusat), Tesis Program Magister Hukum, Fakultas Hukum Universitas Indonesia, Jakarta.

Nopiana, Medi, Agus Maulana, 2017, Urgensi Pembentukan Badan Penyelesaian Sengketa Konsumen di Kabupaten Bekasi Provinsi Jawa Barat. Jurnal Ekonomi dan Bisnis “EQien”, Volume 6 Nomor 1, Februari 2017: 48-55, ISSN: 2503-4413. 